\title{
Hogyan tervezzük a nyugdíjjáradék- függvényt, ha a halandóság a kereset csökkenő függvénye?
}

\begin{abstract}
A nyugdíjrendszerek tervezésénél általában figyelmen kívül hagyják, hogy minél jobban keres valaki, annál tovább él (annál inkább csökken a halandósági ráta), és gyakran annál később megy nyugdíjba. Mivel a magasabb és az alacsonyabb jövedelmúek élettartama közötti különbség egyre nö, egyre kevésbé tartható az e jelenséggel szembeni közömbösség, különösen a befizetéssel meghatározott (notional defined contribution, NDC) eszmei nyugdíjszámlánál. Három egyszerü nyugdíjmodellel elemezzük, hogyan lehet a rövidebb életü szegényebbektől a hosszabb életü jobbmódúakhoz áramló transzfereket csökkenteni vagy megfordítani. Az NDC mellé alapnyugdíjat keverve vagy a nyugdíjemelés bérindexálási súlyát csökkentve, ez megvalósítható. Nyitott kérdés, hogy a figyelmen kívül hagyott viselkedési reakciók (a feltételezett alapnyugdíj mellett kisebb súlyú NDC miatt kisebb munkakínálat és nagyobb jövedelemeltitkolás) és az időnként előálló bérrobbanások hogyan hatnak a jólétre.*

Journal of Economic Literature (JEL) kód: D10, H55.
\end{abstract}

Amikor a kormányzat eltervezi vagy újratervezi a tb-nyugdíjrendszert, két alapfeladatot kell figyelembe vennie: az időskorban kieső jövedelem pótlását és az időskori szegénység csökkentését. Az első feladatot jól látja el a befizetéssel meghatározott (defined contribution, DC) nyugdíjrendszer, míg a második ellátása az alapnyugdíjra (vagy annak módosításaira) hárulhat. A két feladat között a legegyszerübb kompromisszum a két tiszta rendszer megfelelö lineáris kombinációja (lásd Augusztinovics-Matits [2010]). A nyugdíjtervezők általában figyelmen kívül hagyják, hogy a halandóság csökkenő, a nyugdíjazáskor várható élettartam pedig növekvő függvénye az életpálya-keresetnek, ezért túlbecsülik a befizetéssel meghatározott, NDC-rész optimális súlyát. Az utóbbi években azonban egyre nagyobb

* Hálás vagyok Robert Holzmann-nak a téma felvetéséért és Nicholas Barrnak, Borza Gábornak, Hans Fehrnek, Halpern Lászlónak, valamint Lackó Máriának a korábbi változatokhoz nyújtott segítségükért. Köszönettel nyugtázom az OTKA K 108668. számú pályázat támogatását.

Simonovits András, MTA, KRTK Közgazdaság-tudományi Intézet, BME Matematikai Intézet (e-mail: simonovits.andras@krtk.mta.hu).

A kézirat első változata 2018. június 4-én érkezett szerkesztőségünkbe.

DOI: http://dx.doi.org/10.18414/KSZ.2018.7-8.831 
figyelmet kap ennek az elhanyagolt összefüggésnek az erősödése, amely sokunkat a nyugdíjtervezés újragondolására késztet.

A cikkben játszott központi szerepe miatt külön szólunk a keresetarányos rendszer egyik legfontosabb változatáról, a befizetéssel meghatározott eszmei számláról, angol rövidítése alapján NDC-ről (notional defined contribution). Az eszmei számla egy olyan tb-nyugdíjrendszer, amelyben az éves nyugdíj közelítőleg (a kamatozásban alkalmazott technikai reálkamatlábat nullának véve) az életpálya-járulék és a nyugdíjba vonuláskor várható hátralévő élettartam hányadosa. Első megközelítésben a rendszer méltányos és hatékony:

- méltányos, mert a) ugyanazt az éves járadékot adja két olyan dolgozónak, akik közül az egyik kétszer annyit keres, de feleannyi ideig dolgozik, mint a másik; $b$ ) és minden pluszév továbbdolgozásakor a munkás a járadék számlálóján keresztül kisebb és a nevezőjén keresztül nagyobb többletet kap; 40 éves szolgálat és 63 éves nyugdíjba vonulási életkor esetén (20 év hátralévő élettartamot feltételezve) 1 év többletmunka a számlálót 2,5 százalékkal emeli, a nevezőt $4-5$ százalékkal csökkenti;

- hatékony is, mert $a$ ) nem ad kitüntetett szerepet az általános korhatárnak, és $b$ ) amíg a népesség öregszik, a dolgozó vagy tovább dolgozik, vagy a helyettesítési aránya (a nyugdíj és a nettó kereset hányadosa) csökken.

Ismert, hogy az OECD-országokban egymástól jelentősen különböző nyugdíjrendszerek működnek, amelyek az időben is változnak. Több országban domináns a keresetarányos tb-nyugdijrendszer (például Németországban, Franciaországban és Magyarországon is 2011 óta), míg más országokban kisebb és degressziv (gyakran alap-) tbnyugdíjrendszerek müködnek, ${ }^{1}$ amelyeket jelentős magánpillér egészít ki (például az angolszász országokban és Svájcban). Bár általában a tőkésített nyugdíjrendszerekben nem kell életjáradékot venni, de vannak magánrendszerek, amelyekben kötelező, és vannak olyanok, amelyekben választható. Ezekben az országokban a fentiekben felvetett kérdés (hány évig él a nyugdíjas) szintén lényeges lehet.

Amikor a különféle nyugdíjrendszerekben végbemenő jövedelem-újraelosztást vizsgáljuk, figyelembe kell vennünk, hogy a várható élettartam függ a jövedelemtől, különösen azért, mert ez az összefüggés egyre erősebbé válik. Nyilvánvaló, hogy a látszólag arányos nyugdijrendszer valójában torz újraelosztást valósít meg a várhatóan rövidebb élettartamúak terhére és a várhatóan hosszabb élettartamúak javára. ${ }^{2}$ Hasonló a helyzet a látszólag degresszív rendszerekben, amelyek a valóságban inkább semlegesek (hiszen a kisnyugdíjas havi relatív többletnyugdíját az átlagosnál várhatóan rövidebb ideig élvezi). ${ }^{3}$

Két további bonyodalom lép fel. Az első a már említett kontraszelekció: azonos kereseti osztályon belül az egészségesebbeknek hosszabb a várható élettartamuk, és később

\footnotetext{
${ }^{1}$ Definíció szerint adott népességben az éves kezdő nyugdíj százalékosan lassabban emelkedik, mint az átlagos életpálya-jövedelem (amit magyarul degresszív rendszernek nevezünk, azt angolul progressive-nek nevezik).

${ }_{2}^{2}$ Azzal, hogy várható élettartamot írunk, átlagértéket számoltunk, és ezzel már kiszűrtük a minden biztosítási rendszerben fellépő statisztikus ingadozásokat.

${ }^{3}$ A kisnyugdíjas a keresetarányosnál például 20 százalékkal nagyobb nyugdíjat kap, de az átlagosnál 20 százalékkal rövidebb ideig van nyugdíjban, akkor $1,2 \times 0,8=0,96$ miatt nagyjából a pénzénél van.
} 
mennek nyugdíjba. Minden olyan járadékfüggvény (számla), amely közös várható élettartamra épül, jutalmazza a továbbszolgálást és bünteti a korai nyugdíjba vonulást, méltánytalanul kedvez a továbbszolgálóknak, az NDC-rendszer ilyen.

A második bonyodalom a már megállapított nyugdíjak indexálásával kapcsolatos. Különbséget teszünk a kezdeti és a már megállapított nyugdíjak között, $s$ a köztük kapcsolatot teremtő indexálást vizsgáljuk. Két tiszta indexálási forma létezik: a már megállapított nyugdíjak bér- és árindexálása. Az első a jövedelempótlási feladatnak felel meg, a második a szegénységtől mentesít. Kettőjük között folytonosan helyezkednek el a különféle kombinációk. Reálértékekkel számolva csak az az érdekes, hogy a reálbér-indexálás súlya mekkora. Feltéve, hogy a kezdő nyugdíjakat úgy számítják ki, hogy átlagos halandóság esetén egyensúlyba hozza az életpálya be- és kifizetéseit, egy harmadikféle jövedelem-újraelosztás valósul meg (lásd később a 3. MODELLT): a rövidebb élettartamú dolgozók „nyernek” az árindexálással (nagyobbak a kezdő nyugdíjak), a hosszabb élettartamúak veszítenek (lassabban nőnek a már megállapított nyugdijak). A bérindexálásnál pedig fordítva.

Az eredmények bemutatása előtt rátérünk az idevágó szakirodalom rövid ismertetésére. Pestieau-Ponthiere [2016] a halandósági különbségek és a jóléti állam kapcsolatát tekinti át. Talán Buchanan [1968] javasolta elsőként az eszmei számlát, amely valódi pénztőke felhalmozása nélkül is „utánozza” a tőkésített magánnyugdíjrendszert. Azóta több országban (elsőként Svédországban) bevezették az NDC-rendszert (vö. Holzmann-Palmer (szerk.) [2006], Holzmann és szerkesztőtársai [2012]).

Whitehouse-Zaidi [2008], National Academies of Sciences, Engineering, and Medicine [2015], Molnár-Hollósiné [2015] és Auerbach és szerzőtársai [2017] nyomatékosan hangsúlyozza, hogy a várható élettartam keresettől való függőségét egyre kevésbé lehet figyelmen kívül hagyni: statisztikailag a magasabb keresetűek később halnak meg, mint a kisebb keresetűek; sőt e tendencia az évtizedek során élesen erősödött. Ekkor az életpálya-járulék és az évi járadék közti szoros kapcsolatot létesítő modellek (például az NDC) optimalitása kérdéses. Ayuso és szerzőtársai [2016] sugallta jelen cikkünkben három módosítást vizsgálunk: a hagyományos NDCjáradékfüggvény $A$ ) jelzésű zsugorítását, majd ennek $B$ ) és $C$ ) jelzésű módosítását. A $B$ ) esetben az eredeti járadékot a hozzá tartozó várható élettartammal korrigáljuk, a $C$ ) esetben pedig alapnyugdíj hozzákeverésével módosítjuk.

Vélhetőlen Liebmann [2002] volt az első, aki a tb-nyugdíjrendszerben az éves degressziót és az életpálya-degressziót összehasonlította. Empirikusan igazolta, hogy az Egyesült Államok tb-rendszere távolról sem olyan degresszív, mint ahogy az éves nyugdíj és a valorizált életpálya-kereset erősen degresszív képlete alapján gondolnánk (vö. 3. lábjegyzet). Diamond-Orszag [2004] ezen az alapon védte az azóta is müködő amerikai tb-rendszert. Fehr és szerzötársai [2013] a német gazdaság gondosan kalibrált, dinamikus, általános egyensúlyi modelljében határozta meg az optimális tb-rendszer degresszivitását, ahol az átmenet során a már nyugdíjazottak veszteségét központi forrásból fedezik.

Sánchez-Romero-Prskawetz [2017] az Egyesült Államok tb-nyugdíjrendszerének állandósult állapotú, kalibrált általános egyensúlyi modelljében vizsgálta a problémát, 
ahol a kereseti különbségeket az emberitöke-felhalmozás magyarázza; a kereseti és halandósági különbségek csak korrelálnak egymással, de egyik nem határozza meg a másikat, és a kezdő nyugdíj képlete szakaszonként lineáris.

Többen vizsgálták az NDC-rendszer elméleti problémáit (vö. Legros [2006] és Barr-Diamond [2008] 3. fejezet). Alapprobléma: miért kellene rögzíteni a járulékkulcsot egy gyorsan öregedő népesség esetén? Cikkünk szempontjából további három problémát említünk.

Az első probléma a korábban már említett különbség a járadékfüggvény éves degressziója és az életpálya-degresszió között. Ez az NDC-nél is fellép.

Kevésbé fontos, de nem lényegtelen probléma az eszmei számlával kapcsolatban a nyugdíjba vonulási kor választásánál fellépő kontraszelekció (Diamond [2003], Eső-Simonovits [2003], Cremer és szerzőtársai [2004], Eső és szerzötársai [2011] és Simonovits [2012]): akiknek hosszabb a várható élettartamuk, később mennek nyugdíjba, és ezért nyernek az NDC révén, mivel ez a rendszer átlagos várható élettartamra épül.

A már megállapított nyugdíjak indexálása meglehetősen elhanyagolt kérdés az irodalomban (kivétel Simonovits [2003] 14. fejezet, Legros [2006] és különösen Barr-Diamond [2008] 5.1.4. pont, amely megkülönbözteti a magyar szakirodalomban valorizálásnak nevezett fogalmat a kezdő és a már megállapított nyugdíjakat összekapcsoló indexálástól). A problémák fenti leírását Barr-Diamond [2008]-ból vettük át. Feldstein [1990] meglehetősen nagy szabadságot engedett meg magának, amikor az életpálya-nyugdíjtömeg életkor szerinti eloszlását elméletileg optimalizálta. Weinzierl [2014] viszont az egymástól csupán kicsit eltérő amerikai árindexek hatását vizsgálta a nyugdíjasok jólétére.

Az említett források általában elhanyagolták a női és férfiélettartam különbsége és az uniszex tb-nyugdíj közti ellentmondást. Bár van olyan ország (Chile), amelynek kötelező nyugdíjrendszere (tőkésített magánrendszer) külön férfi- és női életjáradékokat számít, de kötelezővé teszi a családosoknak a kombinált életjáradékot. Az általánosan elterjedt özvegyi nyugdíj figyelembevétele jelentősen módosítja a képet (Svédországban viszont az özvegyi nyugdíj már megszűnt).

A jelen dolgozattal csatlakozunk az említett trendhez, és három egyszerü és egymáshoz kapcsolódó nyugdíjmodellel elemezzük a kérdéskört. Mivel el szeretnénk kerülni az optimális munkakínálat (beleértve a nyugdíjba vonulási kor) és az optimális megtakarítási pálya meghatározását, önkényes magatartási szabályokkal dolgozunk. (A Függelékben - az 1.* MODELLBEN - azonban közelítőleg kiszámítjuk az alapmodellben az optimális megtakarítási pályát, és ennek figyelembevételével tanulmányozzuk a társadalmi jólétet optimalizáló kombinációt.) A tárgyalást egyszerűsítendő, nemcsak azt tesszük fel, hogy a népesség stabil, de azt is, hogy stacioner. A keresetfüggö élettartamtól eltekintve modellcsaládunkban nincs halandósági kockázat. A járulékkulcs adott. Mindegyik modellt számpéldán szemléltetjük.

Eredményeink a következők. Az 1. MODELlTőL kezdve együtt élő korosztályokat vizsgálunk, ahol egy adott korosztály dolgozói életpálya-keresetükben különböznek (w), és minden dolgozó $S$ évig fizet járulékot, és a hátralévő $T(w)$ évig élvez változatlan reálértékü nyugdíjat. A nyugdíjrendszernek két pillére van: az arányos, 
befizetéssel meghatározott (NDC) és az alapnyugdíj. A hagyományos NDC-elv három módosítását mérlegeljük: $A$ ) a keresetek és a nyugdíbban töltött időszak hoszszának pozitív korrelációja miatt a hagyományos NDC-t módosítani kell: minden nyugdíjat egy olyan 1-nél kisebb együtthatóval kell zsugorítani, amely helyreállítja a rendszer egyensúlyát; $B$ ) az NDB-nyugdíj nevezőjébe az átlagos várható nyugdíjtartam $[E T(w)]$ helyett a keresettöl függő nyugdijtartamot $[T(w)]$ írunk; $C)$ a zsugorítás mellett bevesszük az alapnyugdíjat is.

A 2. MODELLBEN figyelembe vesszük, hogy a jobban keresők gyakran később mennek nyugdíjba, azaz $S(w)$ szolgálati idő is növekvő függvény, s ezért a hagyományos NDC-beli újraelosztás erősödik.

A 3. MODELLBEN visszatérünk a közös nyugdíjba vonulási korhoz, csak a zsugorítás mellett bevezetjük a tartós reálbérnövekedést és a részleges bérindexálást.

Jelen modelljeinkben nincs optimalizálás (leszámítva a Függelékben szereplö 1.* MODELLT, ahol legalább a kiegészítő megtakarításukat optimalizálják a dolgozók). Önkényes paraméterértékekkel dolgozunk, a várható élettartam a kereset (növekvő) függvénye. Ez az egyszerüsítés a Sánchez-Romero-Prskawetz [2017]-hez képest nemcsak az érthetőséget növeli, de új vonások figyelembevételét is lehetővé teszi: a 2. MODELlben a nyugdíjkorhatár nő a keresettel, a 3. MODELlben a bérindexálás is szerepet kap.

A bevezetés végére érve, négy nyitott kérdést fogalmazunk meg: 1 . Hogyan befolyásolja a kötelező és az önkéntes magánrendszer léte a tb-pillér müködését? (A Függelék szerény kísérlet ebbe az irányba: a magánmegtakarítások reagálnak a jövedelem-újraelosztásra, de a munkakínálat és a keresetbevallás nem.) 2. Milyen mennyiségi kapcsolat van az indexálási súly és az optimális nyugdíbba vonulási kor között? (Simonovits [2018b] óvatos kísérletet tett ennek megválaszolására.) 3. Hogyan változik az alapnyugdíj optimális súlya, ha figyelembe vesszük, hogy a munkakínálat csökkenő függvénye az alapnyugdíj méretének? 4. Hogyan tompítható a bérrobbanás hatása az egymás utáni évjáratok nyugdíjára?

\section{Időben és korban invariáns reálkeresetek, közös nyugdíjba vonulási kor (1. MODELL)}

Az idő- és korfüggő adatok mindvégig állandó árszinten szerepelnek. A következőkben azzal a speciális feltevéssel élünk, hogy az adott évben született dolgozók teljes (szuperbruttó) keresete különböző, de reálértékben időben/korral nem változik. Elsősorban arra vagyunk kíváncsiak, hogy miképpen hat a keresetek és a tőlük függő várható élettartamok heterogenitása a nyugdíjakra.

Feltesszük, hogy az éves keresetek $(w)$ eloszlásfüggvénye $F(w)$. Jelölje a járulékkul$\operatorname{csot} \tau(0 \leq \tau<1)$, a nyugdijba vonulási kort $R$, és a munkába állás korát $L$. A megfelelö hátralévő várható élettartam $e_{R}(\cdot)$, amely nő a keresettel. ${ }^{4}$ Szükségünk lesz a(z éves) járadékfüggvényre: $b(w, R)$ és az életpálya-egyenlegre:

\footnotetext{
${ }^{4}$ Az $R$ alsó index igazából csak a 2. MODELlben kap szerepet.
} 
$z=\tau w(R-L)-b(w, R) e_{R}(w)$.

A hátralévő várható élettartam átlaga $\left[e_{R}=\mathbf{E}_{w} e_{R}(w)\right]$ szerepel a hagyományos NDCjáradékban (az $N$ jelölés az eszmei számla angol kezdőbetủjére utal):

$b^{N}(w, R)=\frac{\tau w(R-L)}{e_{R}}$.

Behelyettesítve (2N)-t (1)-be, adódik a keresetfüggő NDC-egyenleg:

$z^{N}(w, R)=\tau w(R-L)-\frac{\tau w(R-L)}{e_{R}} e_{R}(w)=\frac{\tau w(R-L)}{e_{R}}\left[e_{R}-e_{R}(w)\right]$.

Újra figyelembe véve a (2N) képletet, adódik az 1. TÉTEL.

1. TÉT EL • A hagyományos, (2N) jelzésü NDC-ben a keresetfüggö életpálya-egyenleg a járadék és az átlagos, illetve a specifikus várható élettartam különbségének a szorzata:

$z^{N}(w, R)=b^{N}(w, R)\left[e_{R}-e_{R}(w)\right]$.

Szimmetrikus (vagy más speciális) eloszlásokra definiálhatjuk a $w(R)$ elkülönítö keresetet, amelynél a speciális élettartam egyenlö az átlagossal: $e_{R}[w(R)]=e_{R}$. Könnyü belátni, hogy $e_{R}(w)<e_{R}[w(R)]$, ha $w<w(R) ; e_{R}(w)>e_{R}[w(R)]$, ha $w>w(R)$.

Speciális esetekben a $w(R)$ mennyiség független lehet az $R$ nyugdíjba vonulási kortól, és megegyezhet az átlagkeresettel: $w(R)=\mathbf{E} w=1$. Az 1. TÉTELBŐL adódik a KöVETKEZMÉNY.

Követ KeZmény • a) A hagyományos NDC-ben az átlag alatti várható élettartamú dolgozókra az életpálya-egyenleg pozitiv (vesztesek), azátlag feletti várható élettartamú dolgozókra az életpálya-egyenleg negatív (nyertesek).

b) A várható életpálya-egyenleg negatív.

Bizonyítás • a) Lásd a ( $3 N)$ képletet.

b) Osszuk két részre a kereseteloszlást az elkülönítö bér segítségével. Mivel $b^{N}(\cdot, R)$ növekvő függvény, helyettesíthető $b[w(R), R]$-rel a következő becslésben. Ezzel ugyanis növeljük $z^{N}(w, R)$-t a pozitív értékekre, és csökkentjük a negatív értékekre, azaz $\mathbf{E} z \leq b[w(R), R] \mathbf{E} e_{R}(w)=0$.

Évekkel ezelött Peter Diamond (személyesen) azt tanácsolta, hogy a legegyszerübb az átlagos veszteséget úgy eltüntetni, hogy a $(2 N)$ járadékot minden keresetre azonos $\gamma$ szorzóval csökkentjük (arányosan zsugorítjuk), ez az A) módosítás:

$b^{A}(w, R)=\frac{\gamma^{A} \tau w(R-L)}{e_{R}}=\gamma^{A} b^{N}(1, R) w$.

Behelyettesítve (2A)-t az (1)-be, az új egyenleg

$z^{A}(w, R)=b^{N}(1, R) w\left[e_{R}-\gamma e_{R}(w)\right]$ 
Várható értéket veszünk, és 0 -val egyenlővé tesszük az eredményt:

$0=\mathbf{E} z^{A}(w, R)=b^{N}(1, R) \mathbf{E}\left\{w\left[e_{R}-\gamma e_{R}(w)\right]\right\}$,

innen $\quad \gamma^{A}=\frac{e_{R}}{\mathbf{E}\left[w e_{R}(w)\right]}$.

Figyeljük meg, hogy még ha az $e_{R}(w)$ növekvő voltát azzal az általánosabb feltevéssel helyettesítjük, hogy $w$ és $e_{R}(w)$ korrelációja pozitív $(\mathbf{E} w=1$ miatt), akkor is igaz, hogy $\mathbf{E}\left[w e_{R}(w)\right]>e_{R}$, azaz $\gamma^{A}<1$.

1.A) TÉTEL • Az arányosan zsugoritott (2A) jelzésü ANDC- (kiigazított, adjusted NDC) járadéknál az életpálya-egyenleg az eredeti járadék és az átlagos, illetve a megfelelöen zsugoritott specifikus várható élettartam szorzata [(3A)], ahol $\gamma^{A}$ értékét $(4 A)$ adja.

Követve Ayuso és szerzőtársai [2016]-ot, két további módosítást tanulmányozunk, amely csökkenti vagy akár meg is fordítja az újraelosztást. A B) módosítás egyszerűen $e_{R}(w)$-vel osztja el az életpálya-járulékot $e_{R}$ helyett:

$b^{B}(w, R)=\frac{(R-L) w}{e_{R}(w)} \quad$ és $\quad z^{B}(w, R)=0$.

Ekkor a zsugorító tényező a keresettől függ: $\gamma^{\beta}(w)=e_{R}(w) / e_{R}$, de ezt a megoldást nehéz lenne politikailag érvényesíteni.

A C) módosítás lineárisan kombinálja az NDC-t és az alapnyugdíjat, ahol ez utóbbi $\gamma b^{\circ}=\gamma b(1, R)$, és a relatív súlyok $\alpha>0$ és $1-\alpha>0$. A keverék:

$b^{C}(w, R)=\gamma \alpha b^{N}(w, R)+(1-\alpha) \gamma b^{\circ}, \quad 0 \leq \alpha \leq 1, \quad b^{\circ}=b^{N}(1, R)$.

Behelyettesítve (2C)-t az (1)-be:

$z^{C}(w, R)=b^{\circ} w e_{R}-\left[\alpha \gamma b^{\circ} w+(1-\alpha) \gamma b^{\circ}\right] e_{R}(w)$.

Megint várható értéket képezünk, és 0 -vá tesszük az eredményt:

$0=\mathbf{E}_{w} z^{C}(w, R)=b^{\circ} e_{R}-\alpha \gamma b^{\circ} \mathbf{E}\left[w e_{R}(w)\right]-(1-\alpha) \gamma b^{\circ} e_{R}$.

Ekkor az $\alpha$-tól függő zsugorító $\gamma^{C}$ együttható képlete:

$\gamma^{C}=\frac{e_{R}}{(1-\alpha) e_{R}+\alpha \mathbf{E}\left[w e_{R}(w)\right]}$.

Vegyük észre, hogy $\alpha=1$ esetén a (2C)-(4C) képletsor (2B)-(4B)-re egyszerüsödik. Az $\alpha$ értékét csökkentve, az újraelosztást csökkenthetjük, és irányát meg is fordíthatjuk.

1.B) TÉT EL • A (2B) járadékszabály eltünteti a keresettöl függö élettartam miatti újraelosztást. A (2C)-(4C) járadékszabály gyengíti vagy meg is fordítja a torz újraelosztást.

A következőkben végletesen egyszerủ számpéldán szemléltetjük az elmondottakat. (Más cikkünkben, például Simonovits [2017]-ben reális számpéldákat alkalmaztunk, 
de itt nincs erre szükség.) A típusok száma: $n=3$, súlyuk: $1 / 3$, a járulékkulcs: $\tau=0,25$. Kezdő és záró kor: $L=20, R=60$ év. Az NDC súlya a $C$ )-ben $\alpha=0,5$. Az 1. táblázat 1. és 2. oszlopa közli a típusok keresetét és nyugdíjazáskori várható élettartamát. Figyeljük meg, hogy a kiigazított eszmei számlában (ANDC) a zsugorítási tényező $\gamma^{A}=0,952$; és a kiskeresetü veszteségének abszolút értéke kisebb, mint a nagykeresetü nyeresége: $z_{1}<\left|z_{3}\right|$. A B) módosításnál a kiskeresetü nyugdíja nő, a nagykeresetüé csökken, és az átlagosé változatlan marad. Végül a $C$ ) módosítás $\gamma^{C}=0,976$ zsugorítással tovább növeli a kiskeresetű járadékát, és csökkenti a nagykeresetüét, az előbbi veszteségét nyereséggé, az utóbbi nyereségét veszteséggé téve.

\section{1. táblázat}

NDC-változatok

\begin{tabular}{lcccccc}
\hline \multirow{2}{*}{ Kereset } & \multirow{2}{L}{$\begin{array}{c}\text { MEXP } \\
\text { nyugdíjazáskor }\end{array}$} & \multicolumn{5}{c}{ Módosított NDC } \\
\cline { 2 - 7 } & $A$ járadék & $A$ egyenleg & $B$ járadék & $C$ járadék & $C$ egyenleg \\
\hline$w_{i}$ & $e_{i}$ & $b_{i}^{A}$ & $z_{i}^{A}$ & $b_{i}^{B}$ & $b_{i}^{C}$ & $z_{i}^{C}$ \\
\hline 0,5 & 17 & 0,238 & 0,952 & 0,294 & 0,366 & $-1,220$ \\
1,0 & 20 & 0,476 & 0,476 & 0,500 & 0,488 & 0,244 \\
1,5 & 23 & 0,714 & $-1,429$ & 0,652 & 0,610 & 0,976 \\
\hline
\end{tabular}

$L E X P=$ várható élettartam, $L=20, R=60, \tau=0,25, \alpha=0,5, z_{1}^{B}=z_{2}^{B}=z_{3}^{B}=0$.

\section{Heterogén nyugdíjba vonulási kor (2. MODELL)}

Most rátérünk egy másodlagos, de mégiscsak fontos kérdésre: mi történik, ha az $R(w)$ nyugdíjba vonulási kor szintén heterogén? Elkerülve az életpálya-hasznossági függvény bonyolult maximalizálását, különösen akkor, ha a kormányzat nem ismeri vagy nem használja fel az egyedi várható élettartamokat (vö. Diamond [2003] stb.), egyszerủen feltesszük, hogy minél tovább él egy dolgozó, annál később megy nyugdíjba: $R(w)$ növekvő függvény. ${ }^{5} \mathrm{Meg}$ kell ismételnünk az előző számításokat.

A hagyományos NDC-vel kezdve,

$b^{N}[w, R(w)]=\frac{\tau w[R(w)-L]}{e_{R(w)}}$,

ahol $e_{R(w)}$ az átlagos várható élettartam az $R(w)$ életkorban, függetlenül attól, hogy a dolgozó keresete $w$ vagy sem. Mivel a hosszabb életű és jobban fizetett dolgozók feltevés szerint később mennek nyugdíjba, az $(5 N)$-ben a nyugdíj még inkább növekvő függvénye a keresetnek. Ezért a következmény általánosítható, és az átlagos veszteség fennmarad. A módosított NDC-képletek közül elöször $A$ ) módosítással (a zsugorított eszmei számla) kezdjük.

\footnotetext{
${ }^{5}$ Ez a feltevés nem teljes információn alapul, és még teljes információ esetén is lehetnek más (például családi vagy egészségügyi) okok, amelyek meghatározzák a nyugdíjba vonulási életkort.
} 
$b^{A}[w, R(w)]=\frac{\gamma \tau w[R(w)-L]}{e_{R(w)}}$.

Ezzel szemben a $w$ keresetü és $R(w)$ évesen nyugdíjba vonuló dolgozó várható hátralévő élettartama $e_{R(w)}(w)$, ahol a keresetfüggés explicit. (5A)-t behelyettesítve (3A)-ba: $z^{A}[w, R(w)]=\frac{\tau w[R(w)-L]}{e_{R(w)}}\left[e_{R(w)}-\gamma e_{R(w)}(w)\right]$.

Ismét várható értéket véve, majd nullázva:

$0=\mathbf{E} z^{A}[w, R(w)]=\tau \mathbf{E}\left\{\frac{w[R(w)-L]}{e_{R(w)}}\left[e_{R(w)}-\gamma e_{R(w)}(w)\right]\right\}$,

azaz $\gamma$ meghatározható a következő egyenletből:

$\mathbf{E}\{w[R(w)-L]\}=\gamma^{A} \mathbf{E}\left\{\frac{w[R(w)-L]}{e_{R(w)}} e_{R(w)}(w)\right\}$.

Az előzőkhöz hasonlóan, ismét ugyanazzal a két módosítással csökkenthetjük vagy fordíthatjuk meg az újraelosztást: a $B$ ) szabály az életpálya-járulékot $e_{R(w)}$ helyett $e_{R(w)}(w)$-vel osztja:

$b^{B}(w, R)=\frac{\tau w[R(w)-L]}{e_{R(w)}(w)} \quad$ és $\quad z^{B}[w, R(w)]=0$.

Ismét nehezen elfogadtatható módosítást kaptunk, és inkább keverjük a zsugorított eszmei számlát (ANDC) az alapnyugdíjjal. $\alpha$ súlyt adva NDC-nek $(0 \leq \alpha \leq 1)$, a C) módosítás:

$b^{C}(w, R)=\alpha \frac{\gamma \tau w[R(w)-L]}{e_{R(w)}}+(1-\alpha) \gamma b^{\circ}, \quad b^{\circ}=b^{N}[1, R(1)]$.

Behelyettesítve (5C)-t (1)-be:

$z^{C}[w, R(w)]=\tau w[R(w)-L]-\alpha \frac{\gamma \tau w[R(w)-L]}{e_{R(w)}} e_{R(w)}(w)-(1-\alpha) \gamma b^{\circ} e_{R(w)}(w)$.

Átlagot véve és lenullázva az átlagot:

$0=\tau \mathbf{E}\{w[R(w)-L]\}-\alpha \gamma \tau \mathbf{E} \frac{w[R(w)-L] e_{R(w)}(w)}{e_{R(w)}}-(1-\alpha) \gamma b^{\circ} \mathbf{E} e_{R(w)}(w)$,

azaz

$\tau \mathbf{E}\{w[R(w)-L]\}=\gamma^{C}\left\{\alpha \tau \mathbf{E} \frac{w[R(w)-L] e_{R(w)}(w)}{e_{R(w)}}-(1-\alpha) b^{\circ} \mathbf{E} e_{R(w)}(w)\right\}$.

Az újraelosztás mértékétől függő $\gamma^{C}(6 C)$-ből egyértelmüen meghatározható.

Felhívjuk a figyelmet, hogy $\alpha=1$ esetén a (6C) képlet (6A)-ra egyszerüsödik. Az $\alpha$ súly értékét csökkentve, csökken az újraelosztás, sőt az iránya meg is fordulhat. 
2. TÉTEL • Heterogén nyugdijba vonulási kor esetén az (5A)-(7A) szabályok eltüntetik az átlagos veszteséget. (5B)-(6B) eltünteti az újraelosztást. (5C)-(6C) csökkenti a torz újraelosztást, vagy meg is fordithatja az irányát.

Végül ismét számpéldán szemléltetjük eredményeinket. Heterogén nyugdíjba vonulási kor esetén az $e_{60}(w)=20+6(w-1)$ függvény legegyszerübb általánosítása $e_{R}(w)=80-R+6(w-1)$.

Feltéve, hogy minden dolgozó felnőtt életének $2 / 3$ részét tölti munkával, $R_{1}=58$, $R_{2}=60$ és $R_{3}=62$ év.

A 2. táblázat bemutatja az új eredményeket. A második (nyugdíjba vonulási kor) heterogenitása miatt a $\gamma^{A}$ zsugorítási tényező 0,952-ről 0,939-re csökken, de az egyenlegek kilengése csökken. $z_{1}^{A}$ 0,952-ről 0,897-re mérséklődik. Az aktív és passzív életszakaszok rögzített aránya miatt a $B$ ) módosításkor $b_{i}^{B}=0,5 w_{i}$ fennáll. A $C$ ) módosításkor a $z_{1}^{C}$ veszteség -1,22-ról $+1,89$ nyereségre ugrik, míg a $z_{3}^{C}$ nyereség -0,976-röl 1,654 veszteségre vált.

\section{2. táblázat}

NDC-változatok - heterogén $R$

\begin{tabular}{lccccccc}
\hline \multirow{2}{*}{$\begin{array}{c}\text { Kereset } \\
\text { Nonulási kor }\end{array}$} & LEXP $(R)$ & \multicolumn{5}{c}{ Módosított NDC } \\
\cline { 3 - 8 } & & $A$ járadék & $A$ egyenleg & $B$ járadék & $C$ járadék & $C$ egyenleg \\
\hline$w_{i}$ & $R_{i}$ & $e_{R_{i}}\left(w_{i}\right)$ & $b_{i}^{A}$ & $z_{i}^{A}$ & $b_{i}^{B}$ & $b_{i}^{C}$ & $z_{i}^{C}$ \\
\hline 0,5 & 58 & 19 & 0,203 & 0,897 & 0,25 & 0,349 & $-1,890$ \\
1,0 & 60 & 20 & 0,470 & 0,609 & 0,50 & 0,488 & 0,236 \\
1,5 & 62 & 21 & 0,822 & $-1,506$ & 0,75 & 0,671 & 1,654 \\
\hline
\end{tabular}

Megjegyzés: lásd az 1. táblázat alatti jegyzetet és $R_{i}-L=2\left(D_{i}-L\right) / 3, i=1,2,3$.

\section{A nyugdíjak részleges bérindexálása (3. MODELL)}

Eddig elhanyagoltuk a teljes reálkeresetek hosszú távú emelkedését és a már megállapított nyugdíjak indexálásában fellépő ellentmondást a fogyasztás kisimítása és az újraelosztás csökkentése között. Most rátérünk erre a kérdésre, de közben visszatérünk a közös nyugdíjba vonulási kor feltevéséhez. Feltesszük, hogy a keresetek reálértékben évente egyenletesen $g>1$ tényező szerint nőnek. A már megállapított nyugdíjak azonban reálértékben általában ennél lassabban emelkednek. ${ }^{6}$

Tekintsünk egy adott évben született dolgozót, akinek a kezdő keresete $w_{L}, R$ évesen megy nyugdíjba, és záró keresete $w_{R-1}=w_{L} g^{R-L-1}$. A kezdő nyugdíj kiszámításakor valorizálják az egyes évek keresetét, emiatt a dolgozó NDC-vagyona

\footnotetext{
${ }^{6}$ A 2016-2018 közti hazai reálbérrobbanás az árindexálás miatt hatalmas feszültségeket fog kelteni az adott időszakban nyugdíjba vonuló évjáratok között. Talán mégis vissza kellene térni a bérindexáláshoz, vállalva a kezdő nyugdíjak népszerütlen csökkentését?
} 
$W_{R}=\tau(R-L) w_{R-1}=\tau(R-L) w_{L} g^{R-L-1}$. A már megállapított nyugdíjak idősora $b_{j}$, $j=R, \ldots, D-1$. Az NDC keresztmetszeti várományát tagonként és évente viszont $g$-vel leszámítoljuk:

$B_{R}=\sum_{j=R}^{D-1} g^{-j+R} b_{j}$,

ahol $D=R+e_{R}$ a születéskor várt élettartam.

Vezessünk be egy 0 és 1 közötti $\iota$ skalárt, a bérindex súlyát. Ekkor az egymást követö évek nyugdíja:

$b_{j}=b_{j-1} g^{\prime}, \quad$ ahol $\quad j=R+1, \ldots, D-1$.

Behelyettesítve e képletet az előzőbe:

$\tau(R-L) w_{R-1}=b_{R} \sum_{j=R}^{D-1} g^{-(1-\iota)(j-R)}$.

Felesleges esetszétválasztást $\iota=1$ és $0 \leq \iota<1$ között elkerülendő, vezessük be a következő jelöléseket:

$e_{R}^{(1)}=e_{R}, \quad$ vagy $\quad e_{R}^{(\iota)}=\frac{1-g^{-(1-\iota) e_{R}}}{1-g^{-(1-\iota)}}, \quad$ ha $\quad 0 \leq \iota<1$.

Ekkor a hagyományos NDC-járadék:

$b^{N}\left(w_{R-1}, R\right)=\frac{\tau(R-L) w_{R-1}}{e_{R}^{(\ell)}}$.

Figyeljük meg, hogy minél nagyobb a bérindex $\iota$ súlya, annál nagyobb az indexált $e_{R}^{(\iota)}$ élettartam, és annál kisebb a $b^{N}\left(w_{R-1}, R\right)$ kezdő nyugdíj.

A várható élettartamok heterogenitását figyelembe veendő, $w_{R-1}$ záró bér eloszlásfüggvényét tekintjük adottnak, és kizárjuk az életkorral járó béremelkedést. Normalizálva: $\mathbf{E} w_{R-1}=1$.

A felesleges ismétlést elkerülendő, csak az A) módosítást vizsgáljuk.

$b^{A}\left(w_{R-1}, R\right)=\gamma^{A} \frac{\tau(R-L) w_{R-1}}{e_{R}^{(\ell)}}$.

Bevezetve az $e_{R}^{(1)}\left(w_{R-1}\right)=e_{R}\left(w_{R-1}\right), \quad e_{R}^{(\iota)}\left(w_{R-1}\right)=\frac{1-g^{-(1-\iota) e_{R}\left(w_{R-1}\right)}}{1-g^{-(1-\iota)}}, \quad$ ha $\quad 0 \leq \iota<1$ jelölést, az életpálya-egyenleg most:

$z^{A}\left(w_{R-1}, R\right)=\tau(R-L) w_{R-1}-\gamma b^{N}\left(w_{R-1}, R\right) e_{R}^{(\iota)}\left(w_{R-1}\right)=$

$=b^{N}(1, R) w_{R-1}\left[e_{R}^{(\iota)}-\gamma^{A} e_{R}^{(\iota)}\left(w_{R-1}\right)\right]$.

\footnotetext{
${ }^{7}$ A valóságban a nyugdíjak növekedési tényezője $\iota g+1-\iota=(g-1) \iota+1$.
} 
Megint várható értéket képezve és azt nullának véve:

$0=\mathbf{E} z^{A}\left(w_{R-1}, R\right)=b^{N}(1, R) \mathbf{E} w_{R-1}\left[e_{R}^{(\iota)}-\gamma^{A} e_{R}^{(\iota)}\left(w_{R-1}\right)\right]$.

Innen

$\gamma^{A}=\frac{e_{R}^{(\iota)}}{\mathbf{E}\left[w_{R-1} e_{R}^{(\iota)}\left(w_{R-1}\right)\right]}<1$.

3. TÉTEL • Indexált járadékok esetén a (8A) módositás mellett a zsugoritási együtthatót (11A) adja.

Ezt a részt is számpéldával zárjuk. Legyen a három záró kereset $w_{R-1}(i)=0,5,1,1,5$. A 3. táblázat három indexálást szemléltet $g=1,02$ éves növekedés esetén. Bérindexálás: $\iota=1$; bér-ár-indexálás (vegyes, svájci indexálás): $\iota=0,5$ és árindexálás: $\iota=0$. A megfelelő zsugorítási együtthatók 0,952 és 0,963 között ingadoznak. Ahogy csökken a bérindex súlya, úgy nő a kezdő nyugdíj mindhárom típusra (és úgy csökkennek a 3. táblázatból kihagyott záró nyugdíjak). Figyelemre méltó, hogy bérindexáláskor nemcsak a várhatóan rövid életü, de az átlagos élettartamú dolgozó is hozzájárul a várhatóan hosszú életű dolgozó nyugdíjához. Árindexáláskor fordított a helyzet.

3. táblázat

A járadékok indexálásának hatása a kezdő nyugdíjakra és az egyenlegekre $(A)$

\begin{tabular}{|c|c|c|c|c|c|c|c|}
\hline \multirow[t]{2}{*}{ Kereset } & \multirow{2}{*}{$\begin{array}{c}\text { Hátralévő } \\
\text { LEXP }\end{array}$} & \multicolumn{2}{|c|}{ Bér } & \multicolumn{2}{|c|}{$\begin{array}{c}\text { Bér-ár } \\
\text { indexálás }\end{array}$} & \multicolumn{2}{|c|}{ Ár } \\
\hline & & járadék & egyenleg & járadék & egyenleg & járadék & egyenleg \\
\hline$w_{i, R-1}$ & $e_{i}$ & $b_{i, R-1}^{1}$ & $z_{i, R-1}^{1}$ & $b_{i, R-1}^{0,5}$ & $z_{i, R-1}^{0,5}$ & $b_{i, R-1}^{0}$ & $z_{i, R-1}^{0}$ \\
\hline 0,5 & 17 & 0,238 & 0,952 & 0,263 & 0,870 & 0,289 & 0,791 \\
\hline 1,0 & 20 & 0,476 & 0,476 & 0,525 & 0,420 & 0,577 & 0,369 \\
\hline 1,5 & 23 & 0,714 & $-1,429$ & 0,788 & $-1,290$ & 0,866 & $-1,161$ \\
\hline
\end{tabular}

Megjegyzés: lásd az 1. táblázat alatti jegyzetet és $g=1,02$.

\section{Következtetések}

Három összefüggő NDC-nyugdíjmodellt elemeztünk a hagyományos befizetéssel meghatározott NDC-járadék háromféle módosításával. Az 1. MODELLBEN a dolgozók csak keresetükben és várható élettartamukban különböztek egymástól, de mindnyájan azonos életkorban mentek nyugdíjba. A keresetük és a várható élettartamuk közti pozitív korreláció miatt a hagyományos NDC-nyugdíj erős jövedelemátcsoportosítást hajt végre a rövid várható élettartamú szegényektől a hosszú várható élettartamú gazdagok felé.

A 2. MODELLBEN ez a torz újraelosztás erősödik azáltal, hogy a várhatóan hoszszabb életüek később is mennek nyugdíjba. Mindkét modellben nemcsak eltüntettük 
a hagyományos NDC-rendszer túlzott újraelosztását, de explicit jövedelem-újraelosztással kísérleteztünk.

A 3. MODELLBEN visszatértünk a közös nyugdíjba vonulási korhoz, de a módosításokban figyelembe vettük a tartós reálbérnövekedést és a már megállapított nyugdijak részleges bérindexálását. A legfontosabb nyitott kérdés: hogyan befolyásolja az alapnyugdíj súlya a munkavállalási és járulékfizetési hajlandóságot.

\section{Hivatkozások}

Auerbach, A. És szerzőtársai [2017]: How the Growing Gap in Life Expectancy may Affect Retirement Benefits and Reforms. NBER WP, 23329. Cambridge, MA, https://doi. org/10.3386/w23329.

Augusztinovics Mária-Matits Ágnes [2010]: Pontrendszer és alapnyugdíj (NYp+a) öregséginyugdíj-reform. Megjelent: Holtzer Péter (szerk): Jelentés a Nyugdíj és Időskor Kerekasztal tevékenységéről. Miniszterelnöki Hivatal, Budapest, 234-246. o.

Ayuso, M.-Bravo, J. M.-Holzmann, R. [2016]: Addressing Longevity Heterogeneity in Pension Scheme Design and Reform. IZA Discussion Paper, 10378.

Barr, N.-Diamond, P. [2008]: Reforming Pensions: Principles and Policy Choices. Oxford University Press, Oxford, https://doi.org/10.1017/s0144686x09990730.

Buchanan, J. [1968]: Social Insurance in a Growing Economy: A Proposal for Radical Reform. National Tax Journal, Vol. 21. No. 4. 386-395. o.

Cremer, H.-Lozachmeur, J.-M.-Pestieau, P. [2004]: Social Security, Variable Retirement and Optimal Income Taxation. Journal of Public Economics, Vol. 88. No. 11. 2259-2281. o. https://doi.org/10.1016/j.jpubeco.2003.10.003.

Diamond, P. [2003]: Taxation, Incomplete Markets and Social Security. Munich Lectures. MIT Press, Cambridge, MA.

Diamond, P. A.-Orszag, P. [2004]: Saving Social Security: A Balanced Approach. Brookings Institution, Washington, D. C.

Eső PÉTER-Simonovits ANDRÁs [2003]: Optimális járadékfüggvény tervezése rugalmas nyugdíjrendszerre. Közgazdasági Szemle, 50. évf. 12. sz. 1100-1112. o.

Eső PÉter-Simonovits András-Tóth János [2011]: Designing Benefit Rules for Flexible Retirement: Welfare and Redistribution. Acta Oeconomica, Vol. 61. No. 1. 3-32. o.

Fehr, H.-Kallweit, M.-Kindermann, F. [2013]: Should Pensions be Progressive? European Economic Review, Vol. 63. 94-116. o. https://doi.org/10.1016/j.euroecorev.2013.07.004.

Feldstein, M. S. [1985]: The Optimal Level of Social Security Benefits. Quarterly Journal of Economics, Vol. 100. No. 2. 302-320. o. https://doi.org/10.2307/1885383.

Feldstein, M. S. [1990]: Imperfect Annuity Markets, Unintended Bequest, and the Optimal Age Structure of Social Security Benefits. Journal of Public Economics, Vol. 41. No. 1. 31-43. o. https://doi.org/10.1016/0047-2727(92)90055-k.

Holzmann, R.-Palmer, E. (szerk.) [2006]: Pension Reforms: Issues and Prospects of Nonfinancial Defined Contribution (NDC) Schemes. World Bank, Washington, D. C. https:// doi.org/10.1596/978-0-8213-6038-5.

Holzmann, R.-Palmer, E.-Robalino, D. (szerk.) [2012]: Nonfinancial Defined Contribution Schemes in a Changing World. World Bank, Washington, D. C. https://doi. org/10.1596/978-0-8213-9478-6. 
Legros F. [2006]: NDCs: A Comparison of the French and German Point Systems. Megjelent: Holzmann-Palmer (szerk.), 203-222. o.

Liebmann, J. B. [2002]: Redistribution in the Current U.S. Social Security System. Megjelent: Feldstein, M. A.-Liebmann, J. B. (szerk.): The Distributional Aspects of Social Security and Social Security Reform. Chicago University Press, Chicago, 11-48. o. https://doi. org/10.7208/chicago/9780226241890.003.0002.

MolnáR, D. LÁszló-Hollósiné Marosi Judit [2015]: Az öregségi nyugdíjasok halandósága. Közgazdasági Szemle, 62. évf. 12. sz. 1258-1290. o. https://doi.org/10.18414/ ksz.2015.12.1258.

National Academies of Sciences, Engineering, and Medicine [2015]: The Growing Gap in Life Expectancy by Income: Implications for Federal Programs and Policy Responses. The National Academics Press, Washington, D. C. https://doi.org/10.1111/j.17284457.2015.00099.x.

Pestieau, P.-Ponthiere, G. [2016]: Longevity Variation and the Welfare State. Journal of Economic Demography, Vol. 82. No. 2. 207-239. o. https://doi.org/10.1017/dem.2016.4.

Sánchez-Romero, M.-Prskawetz, A. [2017]: Redistributive Effects of the US Pension System among Individuals with Different Life Expectancy. The Journal of the Economics of Aging, Vol. 10. 51-74. o. https://doi.org/10.1016/j.jeoa.2017.10.002.

Simonovits András [2003]: Nyugdíjrendszerek. Tények és modellek. Typotex, Budapest.

Simonovits András [2012]: Még egyszer az eszmei számla elvi hibájáról. Szigma, 42. évf. 3-4. sz. 145-161. o.

Simonovits ANDRÁs [2017]: A nyugdíjtól függő halandóság és a nyugdíjkiadások hosszú távú előrejelzése. Statisztikai Szemle, 95. évf. 4. sz. 423-431. o. https://doi.org/10.20311/ stat2017.04.hu0423.

Simonovits ANDRÁs [2018a]: Hogyan értékelte alá a tb-nyugdíj optimális szintjét Feldstein 1985-ben? Közgazdasági Szemle, 65. évf. 1. sz. 66- 73. o. https://doi.org/10.18414/ksz.2018.1.66.

Simonovits ANDRÁs [2018b]: Merevség és rugalmasság a magyar nyugdíjrendszerben. Szigma, 59. évf. 1. sz. 1-10. o.

WeinzierL, M. [2014]: Seesaws and Social Security Benefits Indexing. Brookings Papers on Economic Activity, Fall, 137-196. o. https://doi.org/10.1353/eca.2014.0014.

Whitehouse, E.-ZAidi, A. [2008]: Socioeconomic Differences in Mortality: Implications for Pension Policy. OECD Social, Employment and Migration Working Papers, 70. OECD, Párizs, https://doi.org/10.1787/231747416062.

\section{Függelék}

\section{Optimális kombináció és újraelosztás (1.* MODELL)}

Az alábbiakban az NDC-rendszer és az alapnyugdíj társadalmilag optimális kombinációját egy nagyon kezdetleges modellben vizsgáljuk. Definiálnunk kell a dolgozók egyéni életpálya-hasznossági függvényét, amelyeket az egyének optimálisan választott magánmegtakarításukkal maximalizálnak. Az egyszerüség kedvéért eltekintünk ez utóbbiak évenkénti változásától.

Legyen $s$ nem negatív való szám egy $w$ keresetü dolgozó éves megtakarítása, és legyen $\rho(w) \geq 1$ a megfelelő kamatoskamat-tényező. Közelítésként feltesszük, hogy a munka során felhalmozott megtakarítások a folyamat közepére koncentrálódnak, 
és felhasználásuk a nyugdíjas életszakasz felezőpontjára esik. Ezért a kamatoskamattényező az éves kamattényezö ( $\rho[1])$ függvényében: ${ }^{8}$

$\rho(w)=\rho[1]^{\left[R-L+e_{R}(w)\right] / 2}$.

Ekkor az éves fiatalkori és időskori fogyasztási függvények:

$c=(1-\tau) w-s \quad$ és $\quad d=b(w)+\mu(w)^{-1} \rho(w) s, \quad$ ahol $\quad \mu(w)=\frac{e_{R}(w)}{R-L}$.

Az optimális megtakarítás meghatározásához szükségünk lesz egy életpálya-hasznossági függvényre:

$U(w, c, d)=(R-L) \log c+e_{R}(w) \delta(w) \log d$,

ahol a $\delta(w)$ halmozott leszámítolási tényezőt szintén közelítjük:

$\delta(w)=\delta[1, w]^{\left[R-L+e_{R}(w)\right] / 2}$,

és az éves $\delta[1, w]$ leszámítolási tényezőt a kereset növekvő függvényének vesszük. (Ez jól megfelel az empirikus megfigyeléseknek, vö. Simonovits [2018a].)

Behelyettesítve a fogyasztási egyenletpárt a hasznosságfüggvénybe:

$U[w, s]=(R-L)\left\{\log [(1-\tau) w-s]+\mu(w) \delta(w) \log \left[b(w)+\mu(w)^{-1} \rho(w) s\right]\right\}$.

A lokális optimum elsőrendű feltétele szerint

$U_{s}^{\prime}[w, s] \approx-\frac{1}{(1-\tau) w-s}+\frac{\delta(w) \rho(w)}{b(w)+\mu(w)^{-1} \rho(w) s}=0$.

Kifejezve az optimális megtakarítást és kizárva a negatív értéket:

$s(w)=\frac{\left[\delta(w)(1-\tau) w-b(w) \rho(w)^{-1}\right]_{+}}{\mu(w)^{-1}+\delta(w)}$,

ahol a + alsó index a számláló pozitív értékét jelöli.

Feldstein [1985] jóléti megközelítését javítva Simonovits [2018a] társadalmi jóléti függvénye leszámítolás nélkül veszi figyelembe az időskori jólétet:

$V[\alpha, \tau]=(R-L) \mathbf{E}\left\{\log [(1-\tau) w-s(w)]+e_{R}(w) \log [b(w)+\rho(w) s(w)]\right\}$.

Mivel a jólét számszerủ értéke érdektelen, érdemes helyette az úgynevezett relatív hatékonysággal számolni. Ez az az érték ( $(\varepsilon)$, amellyel egységesen beszorozva a transzfer nélküli rendszer béreit, az így adódó új jólét értéke egyenlővé válik az eredeti bérek melletti transzferrendszer jólétével. Képletben:

$V(\alpha, \tau, 1)=V(0,0, \varepsilon)$.

Kihasználva a logaritmikus hasznosságfüggvény sajátosságát,

\footnotetext{
${ }^{8}$ Felhívjuk a figyelmet arra, hogy Pestieau-Ponthiere [2016] eltekintett $\rho(w)$ és $R-L+e_{R}(w)$ kapcsolatától.
} 
$V(0,0, \varepsilon)=V(0,0,1)+\left(R-L+e_{R}\right) \log \varepsilon$,

$\operatorname{azaz} \varepsilon=\exp \left\{[V(\alpha, \tau, 1)-V(0,0,1)] /\left[R-L+e_{R}\right]\right\}$.

Végül az újraelosztás mértékét az egyenleg szórásával definiáljuk: $\mathbf{D} z=\sqrt{\mathbf{E} z^{2}}$. A szokásos számszerű szemléltetéshez szükségünk van a típusfüggő éves leszámítolási tényezőkre: $\delta\left[w_{1}, 1\right]=0,9, \delta\left[w_{2}, 1\right]=0,95, \delta\left[w_{3}, 1\right]=1$, valamint az éves kamattényezőre: $\rho[1]=1,02$. Ez utóbbi értéket úgy választottuk, hogy a korábban önkényesen választott járulékkulcs maximalizálja a jólétet: $\tau^{*}=0,25$, szerencsénkre ez független az NDC súlyától, $\alpha$-tól.

Az F1. táblázat alapján látható, hogy egyszerủ számítógépes számolással adódik, hogy ahogy $\alpha$ 1-ről 0-ra csökken, úgy nő a relatív hasznosság 1,394-ről 1,488-re. Tehát számpéldánkban a tiszta alapnyugdíj adja a társadalmi optimumot. Vegyük azonban figyelembe, hogy az egyenlegek szórása 1,029-ről gyorsan 0,26-ra csökken $(\alpha=0,75$ nál, közel a minimumhoz), majd újra megnő, és ez csökkentheti a munkavállalást és a járulékbevallást.

\section{F1. táblázat}

Az újraelosztás hatása

\begin{tabular}{lcc}
\hline $\begin{array}{l}\text { Az NDC súlya } \\
\alpha\end{array}$ & $\begin{array}{c}\text { Relatív hatékonyság } \\
\varepsilon\end{array}$ & $\begin{array}{c}\text { Az egyenlegek szórása } \\
\mathbf{D} z\end{array}$ \\
\hline 1,00 & 1,394 & 1,029 \\
0,75 & 1,424 & 0,260 \\
0,50 & 1,448 & 0,913 \\
0,25 & 1,470 & 1,867 \\
0,00 & 1,488 & 2,858 \\
\hline
\end{tabular}

Megjegyzés: $\tau=0,25$. 